\title{
The International Capital Flows and The Twin Crisis model Extension of BRICS
}

\author{
Yirong Ying, Feilong Lin, Wuyang Xia \\ College of Economics, Shanghai University, Shanghai, 200444, China
}

Keywords: International capital flows; Twin crisis; BRICS.

Abstract. Under the background of the rapid development of the BRICS, this article research the alternative of Long-term capital and Short-term capital from the difference of returns, then explore the conduction mechanism between the international capital flow and the twin crisis, which is helpful for making safe and effective finance policy to the BRICS.

\section{Introduction}

Since the 1990s, financial crisis had this kind of feature: bank crisis causes currency crisis, currency crisis increases the bank crisis deeply, present an upward spiral situation, which called the twin crisis phenomenon. The first generation currency crisis theory was proposed by Krugman (1979), this theory make the currency crisis as an inevitable result of inharmonious between the domestic economic policies and the fixed exchange rate system. Obstfeld (1986) thought that the twin crisis model has the possibility of self-fulfilling, that is to say, a country's microeconomic system is stability, but when some of these variables is not instability, the deviation of public anticipation makes public lose confidence. Luca et al(2012) examine how the presence of imperfect competition and liability dollarization in banking shapes the real effects of the just mentioned twin crises. Li and Jie(2013) study how effective fiscal and monetary policy responses are during a twin crisis. However, most of the researchers ignore the different remunerations that long-term and short-term domestic investors get, which will make dependency between short-term and long-term capital .That researchers also ignore if there is a dependency , what impact will BRICS suffer when long-term capital leave market lead short-term capital too much or reduce short-term capital lead long-term capital too much. This article make model under this situation, and get conclusion that if dependency existing, the financial system of BRICS will receive the impact because that the leave of long-term capital result in short-term capital too much and reduce of short-term capital result in the increase of long-term capital.

In this paper, we considered the situation that long-term capital is alternative, expand the above model and further discuss the situation. The research of this article will has important reference value and practical significance for BRICS to design policy measures to prevent twin crisis and improve the safety of national economy under the condition of financial system open step by step.

\section{Model Extension and Analysis}

\subsection{Basic Assumption}

Supposing that an open economy system has four types of economic actors: domestic investors 、 international investors domestic bank, domestic central bank. International investors can invest both international market and domestic market or lend to domestic investors. Domestic investors is separate from international market ,they can only invest domestic market and can lend capital from international investors. Domestic central bank can manage foreign exchange. The invest action has three continuous period: $t=0, t=1, t=2$. Open economy system has two types of assets: international assets with safety and mobility ,domestic assets with risk and unmobility. There has two types of all investors:(i)Short-term investors. They finish their invest action in the first period .Supposing that the proportion of international investors in the Short-term investors is $\theta_{1}$ and the domestic investors is $\theta_{2}$.(ii)Long-term investors . They finish their invest action in the second period. The proportion of 
international investors in the Long-term investors is $1-\theta_{1}$ and the domestic investors is $1-\theta_{2}$. The action of international investors, which unchaned, and the action of domestic investors are independent.

The return rate of international assets is $r^{*}$ and the loan rate of international loan is $r^{\prime}$, which all unchanged and $r^{\prime}>r^{*}$. The Short-term profit of domestic assets is $\mathrm{q}$, which is a constant, and the Long-term profit is $\xi$, which obey geometric distribution. Supposing that the total capital of domestic investors is $W_{2}$ in the $\mathrm{t}=0$ period .Domestic investors loan $\mathrm{m}$ from international investors in the $\mathrm{t}=0$ period and loan $n$ from international investors in the $t=1$ period . The quantity of domestic capital withdraw in the $t=1$ period is 1 . The returns of domestic investors in the $t=1$ is $x$ and in the $t=2$ is $y$ .Firstly, we consider Long-term and Short-term capital can not replace each other.

\subsection{Original model}

Under that hypothesis, the target of domestic bank is maximize the expected revenue of domestic investors. When the utility function is $U(W)=-e^{-B W}, B>0$, then $E U\left(W_{2}\right)=-\theta_{2} e^{-B x}-\left(1-\theta_{2}\right) e^{-B y}$ which constrained by:

$$
\begin{gathered}
x \leq a, \\
y \leq b,
\end{gathered}
$$

)

$$
y \geq x
$$

)

$$
x, y \geq 0
$$

)

among which $a=\frac{n+q l}{\theta_{2}}, b=\frac{E[\xi](k-l)-m r^{\prime 2}-n r^{\prime}}{1-\theta_{2}}$.

Proposition 1 If $a>b$, then the system optimum solution is

$$
E U\left(W_{2}\right)=-\theta_{2} e^{-B b}-\left(1-\theta_{2}\right) e^{-B b} \text { at } x=y=b .
$$

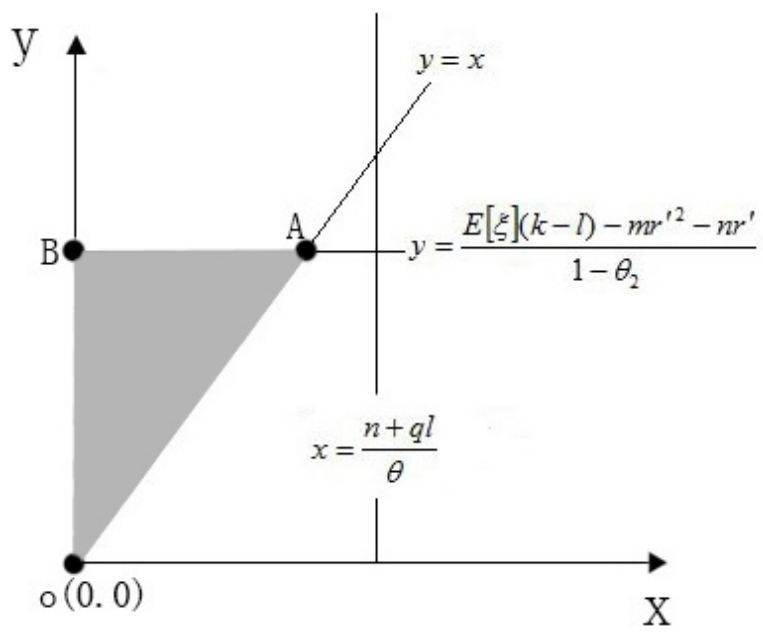

Figure 1

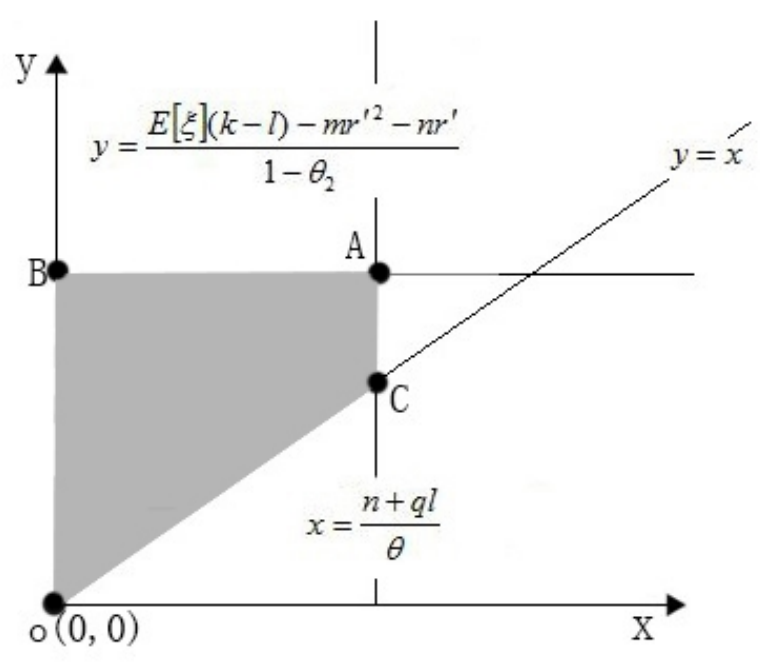

Figure 2

Proposition 1 means that although Short-term investment returns of domestic investors is larger than Long-term investment returns of domestic investors, yet short-term capitals can not replace Long-term capitals, thus the quantity of short-term capitals largely remain unchanged and the financial system can keep safe (see Figure 1).

Proposition 2 If $a<b$, then the system optimum solution is

$$
E U\left(W_{2}\right)_{\max }=-\theta_{2} e^{-B a}-\left(1-\theta_{2}\right) e^{-B b} \text { at } x=a, y=b \text {. }
$$


Proposition 2 means that although Long-term investment returns of domestic investors is larger than Short-term investment returns of domestic investors, yet Long-term capitals can not replace Short-term capitals, thus the quantity of Long-term capitals largely remain unchanged and the financial system can keep safe (see Figure 2).

2.3 Expended model

The above article model ignore the relation between $\mathrm{x}$ and $\mathrm{y}$, the next model consider this relation. Shown as the Figure 3.

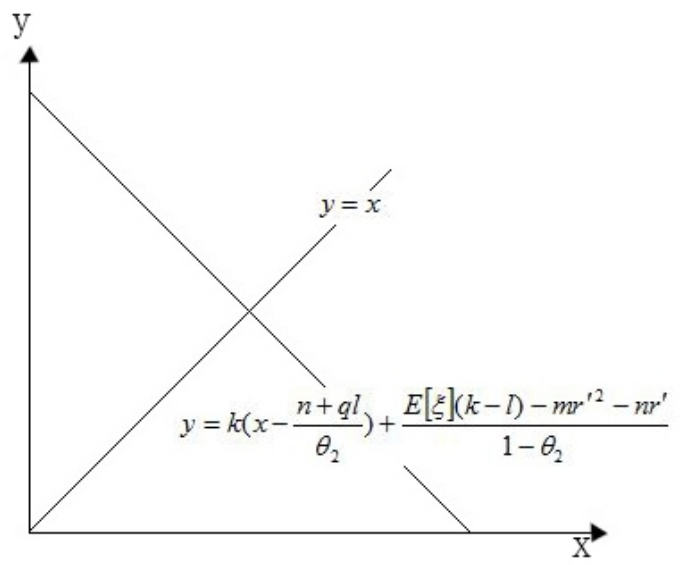

Figure 3

$y=\frac{E[\xi](k-l)-m r^{\prime 2}-n r^{\prime}}{1-\theta_{2}}+k\left(x-\frac{n+q l}{\theta_{2}}\right)$, this equation is a simple linear regression model, $\mathrm{y}$ is a explained variable meaning the returns of Long-term capital and $\mathrm{x}$ is a explanatory variable meaning the returns of Short-time capital.The slope $\mathrm{k}$ means the co-relativity of $\mathrm{x}$ and $\mathrm{y}$. When the value of $\mathrm{k}$ is too large ,which means the Short-term capital can replace the Long-term capital ,thus the Short-term capital increase and the domestic financial market of BRICS suffer shock .On the contrary, the co-relativity of $x$ and $y$ is too weak, which means the Long-term capital and the Short-term capital not fluctuate and the financial market keep safe.

When the utility function is $U(W)=-e^{-B W}, B>0$, then $E U\left(W_{2}\right)=-\theta_{2} e^{-B x}-\left(1-\theta_{2}\right) e^{-B y}$, however, the constrained condition becomes:

$$
\begin{gathered}
y \leq k(x-a)+b, \\
x, y \geq 0,
\end{gathered}
$$

Proposition 3 If $a>b$, then the optimum problem (1)-(2) is

$$
E U\left(W_{2}\right)_{\max }=-\theta_{2} e^{-\frac{B(b-k a)}{1-k}}-\left(1-\theta_{2}\right) e^{-\frac{B(b-k a)}{1-k}} \text { at } x=y=\frac{b-k a}{1-k} .
$$

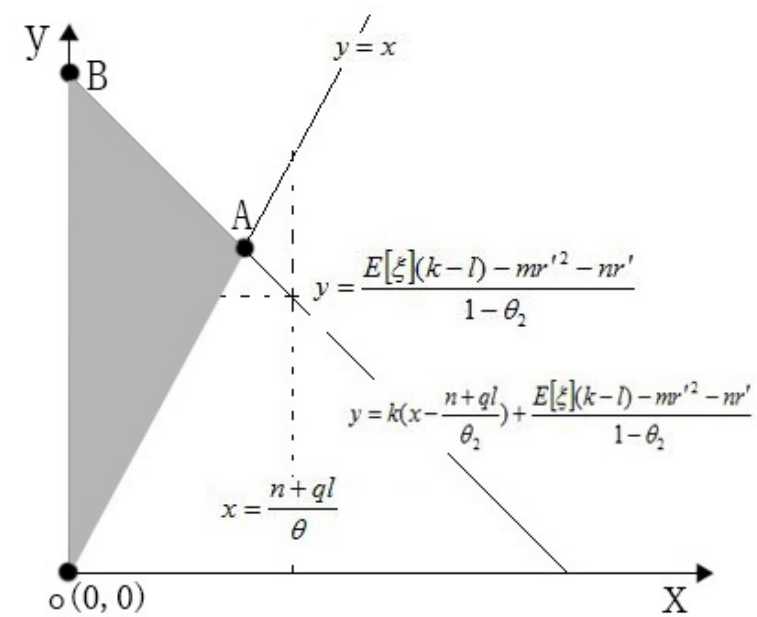

Figure 4

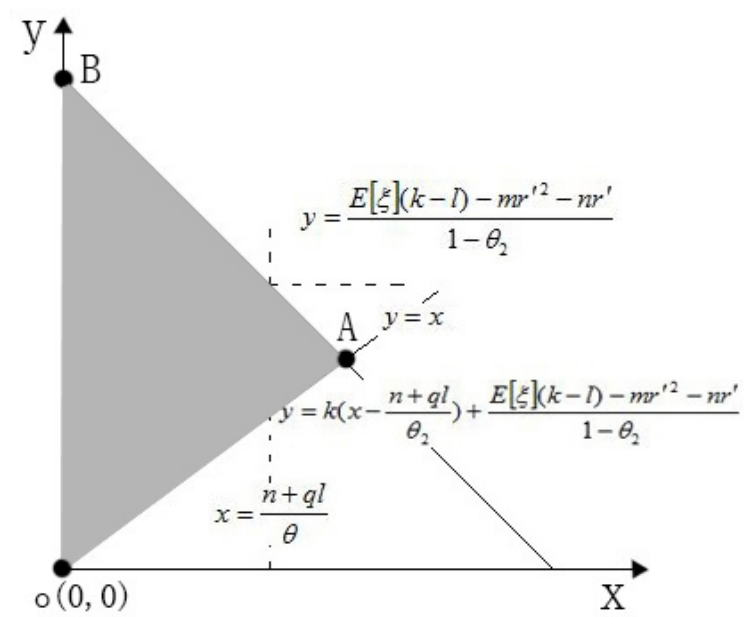

Figure 5 
Proposition 3 means that Short-term investment returns of domestic investors is larger than Long-term investment returns of domestic investors, thus the quantity of Short-term capitals largely increase and the financial system has become unsafe (see Figure 4).

Proposition 4 If $a<b$, then the optimum problem (1)-(2) is

$$
E U\left(W_{2}\right)_{\max }=-\theta_{2} e^{-\frac{B(b-k a)}{1-k}}-\left(1-\theta_{2}\right) e^{-\frac{B(b-k a)}{1-k}} \text { at } x=y=\frac{b-k a}{1-k} .
$$

Proposition 4 means that Long-term investment returns of domestic investors is larger than Short-term investment returns of domestic investors, thus the quantity of Long-term capitals largely increase and the financial system has become unsafe (see Figure 5).

\section{Conclusions}

Considering the substitutive relationship between Long-term capital and Short-term capital ,the main reason of twin crises is Long-term capital and Short-term capital can substitute each other, which occurs their returns exist difference. For that reason ,the domestic central bank loss the ability of controlling the domestic bank system and international capital can poured into domestic capital market ,which makes domestic financial system suffering shock. BRICS , which financial system imperfect and lacking of regulation means, vulnerable to the impact of international capital because the domestic financial market continues to open .Thus domestic central bank or foreign exchange administration ought to strengthen the supervision ability and manage the type and maturity of international capital ,they also need to supervise the proportion of foreign loans and prevent a large number of international capital poured into domestic financial market, which can cause huge impact for finance and Economy.

The process of financial Liberalization need to prudently implement and according to different countries ability .This process of BRICS can optimize the allocation of capital efficiency and at the same time it will wider the quantities of international capital inflows and outflows, intensify the risk of financial crisis. The open of BRICS financial market should be step by step. The central bank or the foreign exchange manage department should strengthen the international payment, especially the international capital project, supervision and master the scale of international capital flow, and also set up monitoring and early warning mechanisms . Under the situation of promoting the liberalization of financial market and capital flow, financial department must ensure the safety and efficiency operation of financial system.

\section{Acknowledgements}

This work was financially supported by the National Natural Science Foundation (71171128).

\section{References}

[1] Krugman,P., A Model of Balance of Payments Crises[J].Journal of Money, Credit and Banking. Vol.11 (1979):311-325

[2] Obstfeld.M., Maurice. Rational and self-fulfilling Balance-of-Payments Crises[J].Amercian Economic Review. Vol.76(1986):72-81.

[3] Luca, Alina C, Olivero, MaríaPía. Twin Crises in Emerging Markets: The Role of Liability Dollarization and Imperfect Competition in Banking[J].Review of Development Economics. Vol. 16(2012):72-94.

[4] Li, Jie. The effectiveness of fiscal and monetary policy responses to twin crises[J].Applied Economics .Vol.45(2013):3904-3913. 